\title{
Biodegradation of LDPE plastic by local strain of Bacillus sp. isolated from dump soil of Pekanbaru, Indonesia
}

\author{
BERNADETA LENI FIBRIARTI ${ }^{1, \vartheta}$, FELIATRA $^{2}$, BINTAL AMIN $^{2}$, DARWIS $^{2}$ \\ ${ }^{1}$ Department of Biology, Faculty of Mathematics and Natural Sciences, Universitas Riau. Jl. HR Soebrantas Km 12,5, Kampus Bina Widya, Simpang \\ Baru, Pekanbaru 28291, Riau, Indonesia. Tel./fax.: +62-0761-63273, ^email: bernadeta.leni@lecturer.unri.ac.id \\ ${ }^{2}$ Faculty of Fisheries and Marine Science, Universitas Riau. Jl. HR Soebrantas Km 12,5, Kampus Bina Widya, Simpang Baru, Pekanbaru 28291, Riau, \\ Indonesia
}

Manuscript received: 20 August 2021. Revision accepted: 25 November 2021

\begin{abstract}
Fibriarti BL, Feliatra, Amin B, Darwis. 2021. Biodegradation of LDPE plastic by local strain of Bacillus sp. isolated from Dump Soil Pekanbaru, Indonesia. Biodiversitas 22: 5484-5490. Plastic is a compound resistant to degradation and takes tens to hundreds of years to decompose completely. The diversity of microbial metabolism allows microbes to degrade plastic and utilize it as a source of energy and carbon for growth. One type of plastic widely used in packaging is LDPE (Low-Density Polyethylene). The purpose of this study was to test the ability of local isolates of Bacillus sp. strains BP4 and BP6 isolated from waste soil and to identify them at molecular level. In LDPE plastic degradation test, pieces of LDPE plastic were added as a carbon source to a mineral solution medium and incubated for 30 days on shaker incubator at $150 \mathrm{rpm}$. The percentage of plastic degradation was calculated by subtracting the percentage of the initial weight of the plastic with the final weight. The test results showed that two isolates i.e. BP4 and BP6 were able to degrade LDPE plastics with degradation percentages of $7.23 \pm 0.64 \%$ and $8.19 \pm 0.12 \%$, respectively. Molecular identification results revealed that Bacillus sp. strain BP4 showed a similarity of $99.72 \%$ with Bacillus anthracis strain X11, while Bacillus sp. strain BP6 showed a similarity of $99.93 \%$ with Bacillus paramycoides strain 8929.
\end{abstract}

Keywords: Bacillus sp., LDPE plastic, local bacteria, plastic degradation

Abbreviations: LDPE: Low-Density Polyethylene

\section{INTRODUCTION}

Over the past three decades, plastic has been increasingly used in various fields, the most widely used as packaging or carrying bags. The Global consumption of plastic bags is estimated at $0.5-1$ trillion annually. Plastic is a xenobiotic compound resistant to degradation, so it takes tens to hundreds of years to completely decompose (Nielsen et al. 2019). The accumulation of plastic waste is still a major problem, especially in urban areas. Plastic is part of urban waste with a fairly large percentage. Basori (2016) reported that the amount of plastic bag waste produced by TPS (Trash Disposal Sites) in Pekanbaru was 38.4 tons/day with a dry weight of 23.8 tons/day or $15.9 \%$ of the dry weight of waste. Plastic waste that cannot be recycled will be stored in the TPA (Final Disposal Site). Landfilling in the landfill will form an anaerobic environment, resulting in complex biochemical reactions that lead to leachate formation. This condition can cause the plastic to be fragmented into microplastics, later entering the waters (He et al. 2019).

The nature of plastic that is difficult to degrade, bury the plastic. This pile of plastic waste through the water flow will enter the ocean, fragmented into microplastics, which accumulate and enter the food chain. Plastic waste polluting the sea causes a negative environmental image and negatively impacts open ecosystem spaces (Tosetto et al. 2016). de Souza Machado et al. (2018) noted that plastic pollution causes several global changes to terrestrial ecosystems. Plastic that accumulates reduces soil fertility, block water absorption by plants and threaten animal life. Dumping garbage in the landfill requires a large area of land, this land should be used for more production facilities, such as agriculture. Burning plastic waste can cause the release of hazardous chemical compounds into the atmosphere such as carbon-based free radicals, PAHs (Polycyclic Aromatic Hydrocarbons), PCBs (Poly Chlorinated Biphenyl), heavy metals, $\mathrm{CO}_{2}, \mathrm{NO}_{2}, \mathrm{SO}_{2}$, dioxins, and poly chloro dibenzofurans. This compound when inhaled will cause several dangerous diseases such as nervous system disorders in humans, cancer, liver swelling, and nervous system disorders.

Plastics are long-chain polymers derived from fossil fuels. Plastics are found in various forms of everyday life such as polyvinyl chloride, polycarbonate, polyethylene, nylon, polystyrene, polyethylene terephthalate, polypropylene, (Raziyafathima et al. 2016). One type of plastic that is widely used for packaging and agriculture is LDPE (Low-Density Polyethylene). The structure of LDPE is very stable and resistant to degradation because it has hydrophobicity and high molecular weight. Plastic biodegradability is also determined by chemical and physical characteristics, such as molecular density, morphology, structural complexity, chain bonds, molecular composition, and the physical properties and shape of polymers (film, pellet, powder or fiber). Plastics can be 
degraded through thermal, chemical, and biological mechanisms. Plastic degradation is a physical or chemical change in a plastic polymer caused by environmental conditions such as heat, light, humidity, biological activity or chemical conditions.

The role of microbes in plastic biodegradation is very important. Bacteria are organisms that have the widest distribution and can live and survive in various habitats in nature. Bacteria can decompose complex compounds into simpler compounds to obtain certain substances necessary for their growth. Bacteria are the most important organisms that play a role in the process of decomposition. Microbial biodegradation is one solution to the problem of plastic accumulation in nature that is safe and environmentally friendly because plastic can be completely degraded and does not produce secondary pollutants. Various types of microbes are known to be able to degrade various different types of plastics. Research has shown that Bacillus genera with have the ability to degrade various type of plastics such as Bacillus amyloliquefaciens, Bacillus mycoides, Bacillus cereus, Bacillus thuringiensis, Bacillus pumilu, (Sharma and Sharma 2004), B. cereus (Suresh et al. 2011), Brevibacillus brevis (Watanabe et al. 2009), Bacillus siamens and B. cereus (Lalina et al. 2021), Bacillus ISJ51 (Gupta and Devi 2019). The genus Bacillus has the potential to be developed in the biotechnology industry because it has several properties such as having a wide growth temperature range, being able to form spores, being cosmopolitan, resistant to antiseptic compounds, being aerobic or facultatively anaerobic, having various enzymatic abilities, and some of them are capable of biodegrading some recalcitrant and xenobiotic compounds.

The richness and diversity of microbes, especially local bacteria, must be explored and utilized to solve environmental problems. Research on Riau's local Bacillus bacteria capable of degrading LDPE plastic has never been done before. In this study, the ability of 2 local Riau Bacillus isolates to degrade LDPE plastic was followed by characterization and molecular identification of the bacteria. The results of this study are expected to obtain local bacteria that can degrade LDPE plastic. Exploration and utilization of this microbial diversity is also an effort to save and protect the genes of local Riau species.

\section{MATERIALS AND METHODS}

\section{LDPE plastic degradation test}

The inoculum of Bacillus sp. strains BP4 and BP6 used for the biodegradation test was $10^{6} \mathrm{CFU} / \mathrm{mL}$. Plastic sterilization was carried out by soaking in $70 \%$ alcohol for 30 minutes and drying in an incubator at $60^{\circ} \mathrm{C}$ for 15 minutes. A $10 \mathrm{~mL}$ bacterial inoculum was mixed in 100 $\mathrm{mL}$ mineral solution medium and then inoculated sterilized pieces of LDPE plastic bag (10x3). LDPE plastic was the only carbon source in the medium. Then it was incubated for 30 days on a shaker at incubator at speed of $150 \mathrm{rpm}$ at room temperature. Control treatment was also maintained without the addition of bacterial isolates. At the beginning and end of the incubation, test plastic was sterilized with alcohol (70\%) soaked for 30 minutes and dried in an oven incubator at a temperature of $60^{\circ} \mathrm{C}$ for 15 minutes. Then do the weighing of the pieces of the plastic test. Furthermore, the percentage of degradation was calculated according to the formula. Whereas $\mathrm{W} 1$ is the weight (initial) of plastic before testing and Wf is the weight (final) of plastic after testing (Kyaw et al. 2012).

$$
\frac{(\mathrm{W} 1-\mathrm{Wf})}{\mathrm{W} 1} \times 100 \%
$$

\section{Morphological characterization and biochemical tests}

The morphological characterization was based on partial characterization, including colony morphology (size, color, shape, edge, and elevation). Colony morphology was characterized by direct observation of the bacterial colonies of Bacillus sp. strains BP4 and BP6 grown in Petridish. Gram's staining was also performed to observe that whether the bacteria were Gram positive or Gram negative. Gram staining included the application of crystal violet (primary stain), iodine (mordant), alcohol 96\% (decolorization), and Safranin (counterstain). Each step has given after washing with running water. Observations were made using a microscope. The group of Gram-negative bacteria if it was pink and the group of Gram-positive bacteria if it was purple. Growing bacteria carried out a Carbohydrate fermentation test on glucose, sucrose, and fructose medium with the addition of phenol red indicator. Then Incubated for 24-48 hours and observed for changes in the color of the medium and the presence or absence of gas. The motility test was carried out to grow Bacillus sp. strains BP4 and BP6 isolates on Trypticase Soy Broth medium. Motility was observed using a microscope. The catalase test was carried out by observing the presence or absence of air bubbles in bacterial colonies dripped with $3 \% \mathrm{H}_{2} \mathrm{O}_{2}$ solution. The growth ability test was conducted by growing bacteria on a Nutrient agar medium and incubating at several temperature variations $(25,30,37$, and $\left.42^{\circ} \mathrm{C}\right)$. This test was conducted to determine the viability of bacteria at low, medium, and high temperatures. The growth ability test at several $\mathrm{pH}$ variations was carried out by growing bacteria on media that had adjusted the $\mathrm{pH}(5,6,7$ and 8) (Bisen et al. 2012).

\section{Molecular identification based on $16 \mathrm{~S}$ rRNA sequences Bacterial DNA extraction}

Each of $2 \mathrm{~mL}$ of Bacillus sp. strains BP4 and BP6 cultures was added with Tris-EDTA (Ethylene Diamine Tetra Acetyc Acid) buffer. Next, $1.5 \mathrm{~mL}$ of bacterial culture was put into an Eppendorf tube and centrifuged at $14,000 \mathrm{rpm}$ for 1 minute. Bacterial cultures in liquid medium incubated in a incubator shaker for 24 hours. Subsequently, $1.5 \mathrm{~mL}$ of the culture was centrifuged at $14,000 \mathrm{rpm}$ for 1 minute. Then the DNA was extracted using the Presto ${ }^{\mathrm{TM}}$ Mini gDNA Bacteria Kit.

\section{S rRNA gene amplification}

The $16 \mathrm{~S}$ rRNA gene was amplified using universal primers 27F (5'-(GATTTTGATCMTGGCTCAG-3') and 1492 R (5'-GGTTACCTTGTTACGACTT-31. The PCR 
component consisted of primer $27 \mathrm{~F}(0.2 \mathrm{M} ; 11)$, primer 1492R (0 ,2 M;1 1), DNA template (1 1), $2 \mathrm{X}$ at Taq Master Mix 1X (25 l) and sterile $\mathrm{ddH}_{2} \mathrm{O}(22 \mathrm{l})$. PCR reaction with first heating at $94^{\circ} \mathrm{C}$ for 5 minutes, then followed by 35 cycles consisting of denaturation (1 minute) at $94^{\circ} \mathrm{C}$, annealing (1 minute) at $56^{\circ} \mathrm{C}$ and 2 minutes of extension at $72^{\circ} \mathrm{C}$. After 35 cycles were completed, followed by 4 minutes at $72^{\circ} \mathrm{C}$ and cooling at $4^{\circ} \mathrm{C}$ for 30 minutes. The amplification results were fractionated by electrophoresis on $1 \%$ agarose gel in TEA buffer (Tris-EDTA) for 20 minutes at $100 \mathrm{~V}$. The gel from the electrophoretic was immersed in a solution of ethidium bromide solution with a concentration of $1 \mathrm{~L} / 100 \mathrm{~mL}$ for 15 minutes. The separation results were visualized on the Gel. Doc Print Graph using UV transilluminator with 100 bp. Standard DNA ladder (Promega) to determine the yield and a band size of the amplified DNA. The amplified sample was 481 in a PCR tube coated with parafilm. Sequencing was performed using the Bio Trace model 3100 machine. Sequencing results were analyzed using the BioEdit program and BLAST in the NCBI gene bank followed by phylogenetic analysis using the MEGA 6 program (Tamura et al. 2011).

\section{RESULTS AND DISCUSSION}

\section{Plastic degradation test}

The results of the LDPE plastic degradation test showed that both Bacillus strain BP4 and strain BP6 could degrade LDPE plastic as shown in Table 1. The decrease in the weight of the test plastic was due to bacterial activity, whereas $0 \%$ degradation was recorded in control treatment isolates.

\section{Morphological characterization and biochemical tests}

The results of biochemical and morphological tests of the two Bacillus isolates are shown in Table 3. Bacillus sp. strains BP4 and BP6 were Gram-positive and rod-shaped bacteria.

The carbohydrate fermentation test result showed that both Bacillus isolates could ferment glucose and were unable to ferment sucrose and fructose. A positive test was indicated by a color change in the glucose medium with the addition of phenol red indicator from red to yellow. The result of the carbohydrate fermentation. The results of the carbohydrate fermentation test are presented in Figure 2.

The catalase test result of both Bacillus sp. BP4 and BP6 isolates showed positive tests. This reaction was marked by the formation of oxygen bubbles, on the bacterial isolates dripped with $\mathrm{H}_{2} \mathrm{O}_{2}$. Motility test results showed strain BP4 and strained BP6 were motile. Both isolates of Bacillus sp. strain BP4 and BP6 are capable of growing at a temperature range of $25-42^{\circ} \mathrm{C}$ and can grow in a $\mathrm{pH}$ range of 6-8.

\section{Molecular identification (16S rRNA gene sequences)}

The results of molecular identification exhibited that Bacillus sp. strain BP4 and BP6 produced DNA band of $1443 \mathrm{bp}$ and $1439 \mathrm{bp}$ respectively. Furthermore, BLASTn analysis was carried out to observe its similarity with other bacterial sequences in the gene bank. The results of BLAST analysis showed that Bacillus sp. strain BP4 similar sequences to Bacillus paramycoides strain 8929 (99.72\%), Bacillus anthracis strain X11 (99.72\%), B. anthracis strain FDAARGOS_695 (99.65\%), B. anthracis strain FDAARGOS_695 $(99.65 \%), B$. anthracis strain FDAARGOS_702 $(99.65 \%), \quad B$. anthracis strain FDAARGOS_703 $(99.65 \%), \quad B$. thuringiensis strain FDAARGOS_791 $(99.65 \%), \quad B$. thuringiensis strain FDAARGOS_792 $(99.65 \%), B$. thuringiensis strain FDAARGOS_794 $(99.65 \%), \quad B . \quad$ cereus strain FDAARGOS_797 $(99.65 \%), \quad B . \quad$ cereus strain FDAARGOS_780 (99.65\%). The results of MEGA analysis in the phylogenetic tree are shown in Figure 3.

The results of the molecular identification of Bacillus sp. strain BP6 bacteria produced DNA band measuring 1439 bp. Furthermore, BLASTn analysis was carried out to see the similarity with other bacterial sequences in the gene bank. The results of BLASTn analysis showed that Bacillus sp. strain BP6 had similarities with B. paramycoides strain 8929 (99.93\%), B. anthracis strain FDAARGOS_695 (99.86\%), B. anthracis strain FDAARGOS_702 (99.86\%), $B$. anthracis strain FDAARGOS_703 $(99.86 \%), B$. thuringiensis strain FDAARGOS_791 (99.86\%), $B$. thuringiensis strain FDAARGOS_794 (99.86\%), B. cereus strain FDAARGOS_797 $(99.86 \%), \quad$ B. cereus strain FDAARGOS_780 $(99.86 \%), \quad B$. cereus strain FDAARGOS_781 (99.86\%). The results of MEGA analysis in the phylogenetic tree are shown in Figure 4.

Table 1. Percentage of weight loss of LDPE plastic

\begin{tabular}{cccc}
\hline Isolate & Control & \% weight reduction & Time (days) \\
\hline BP4 & $0.00 \pm 0.00$ & $7.23 \pm 0.64$ & 30 \\
BP6 & $0.00 \pm 0.00$ & $8.19 \pm 0.12$ & 30 \\
\hline
\end{tabular}

Table 2. Comparison of different of Bacillus strains capable of degrading LDPE

\begin{tabular}{llccc}
\hline Strain & Isolation source & Incubation (days) & \% weight reduction & Reference \\
\hline Bacillus sp. strain BP4 & Dump soil Riau Indonesia & 30 & 7.23 & This study \\
Bacillus sp. strain BP6 & Dump soil Riau Indonesia & 30 & 8.19 & This study \\
Bacillus siamens & Waste disposal & 90 & 8.46 & Lalina et al. (2021) \\
Bacillus cereus & Waste disposal & 90 & 6.33 & Lalina et al. (2021) \\
Bacillus ISJ51 & Plastic adhered soil & 60 & 1.5 & Gupta and Devi (2019) \\
\hline
\end{tabular}



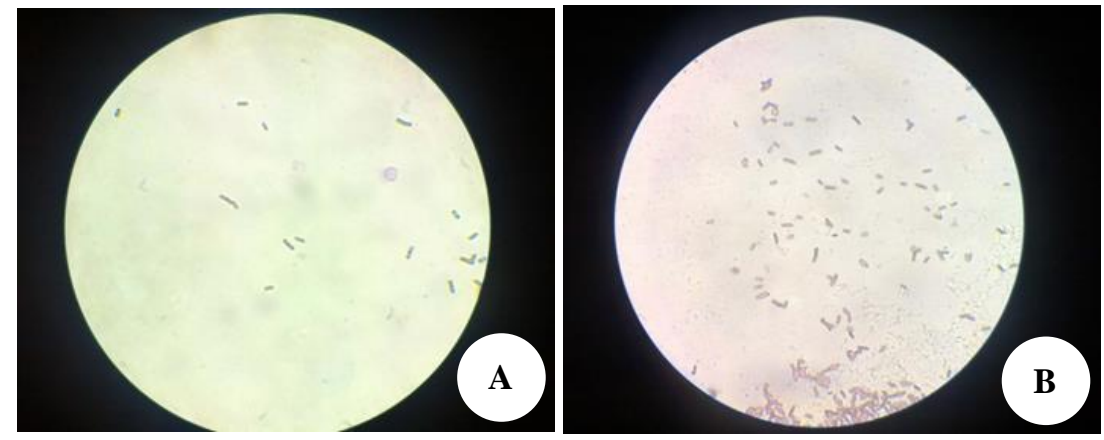

Figure 1. Gram staining of bacterial isolates at $1000 \mathrm{x}$ magnification, A. Bacillus sp. strain BP4, B. Bacillus sp. strain BP6
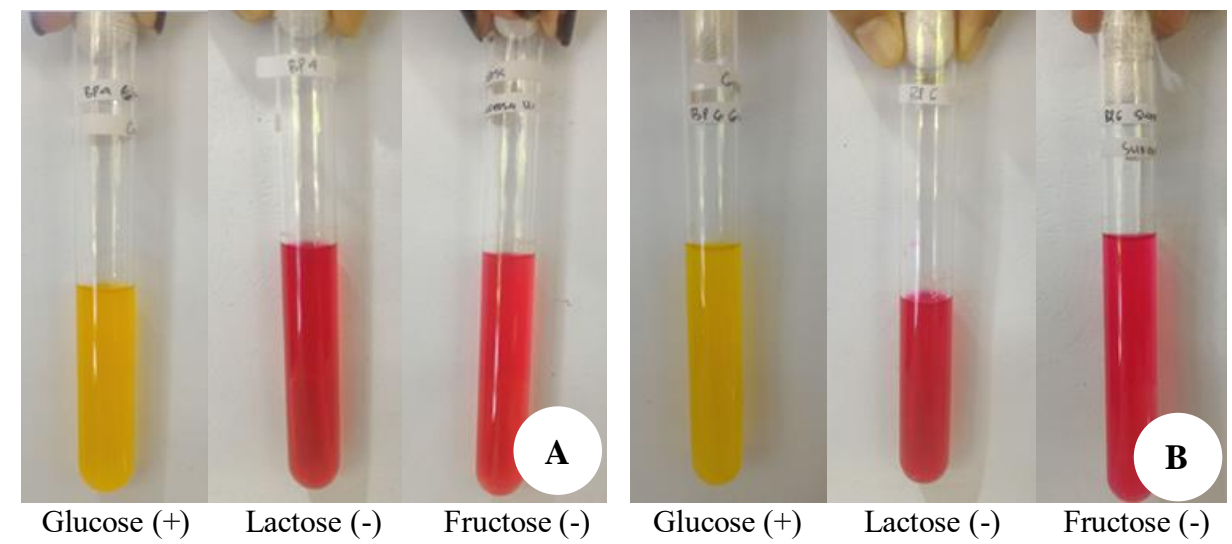

Figure 2. Carbohydrate fermentation test results, A. Bacillus sp. strain BP4, B. Bacillus sp. strain BP6

\section{Discussion}

\section{Plastic degradation test}

The results of the LDPE plastic degradation test showed that both strain BP4 and strain BP6 could degrade LDPE plastic. Both local Bacillus sp. isolates could degrade LDPE well within 30 days. Bacillus sp. strain BP4 showed the percentage of LDPE plastic degradation of $7.23 \pm$ $0.64 \%$ and Bacillus sp. strain BP6 with the percentage of LDPE plastic degradation of $8.19 \pm 0.12 \%$. The decrease in the weight of the test plastic was caused by bacterial activity, this was strengthened by the control treatment without the addition of bacterial isolates which showed a percentage of $0 \%$ degradation in the 30 days incubation time. This result is quite good considering that LDPE is a type of plastic that is very stable and difficult to degrade. This is because LDPE is polyethylene with high hydrophobicity and a high molecular weight of more than $30 \mathrm{kDa}$. The mechanism of plastic degradation by bacteria begins with the attachment of bacteria to the plastic surface, bacteria excrete enzymes that can break down the main chain and form low molecular weight fragments (Alshehrei 2017). The mechanism of plastic degradation begins with the conversion of LDPE into monomers so that they can enter the bacterial cell membrane. In this study, it is hypothesized that strain BP4 and strain BP6 excrete enzymes that can depolymerize LDPE plastic into monomers, then the monomers are absorbed by bacterial cells and decompose naturally used as a carbon source for bacterial growth. Bacterial extracellular enzymes degrade complex polymers to produce smaller oligomers, dimers, and monomers. These short-chain molecules can be used as a source of energy and carbon and then mineralized into end products such as $\mathrm{CO}_{2}, \mathrm{H}_{2} \mathrm{O}$, or $\mathrm{CH}_{4}(\mathrm{Gu} 2003)$.

Table 3. Characteristics of strain BP4 and strain BP6

\begin{tabular}{lcc}
\hline \multicolumn{1}{c}{ Test } & $\begin{array}{c}\text { Bacillus sp. } \\
\text { strain BP4 }\end{array}$ & $\begin{array}{c}\text { Bacillus sp. } \\
\text { strain BP6 }\end{array}$ \\
\hline Form & Basil & Basil \\
Colony size & Medium & Medium \\
Colony color & White & Cloudy white \\
Colony shape & Circular & Irregular \\
Colony edge & Entire & Entire \\
Colony elevation & Raised & Raised \\
Gram stain & + & + \\
Motility & + & + \\
Catalase & + & + \\
Glucose Fermentation & + & + \\
Lactose Fermentation & - & - \\
Sucrose fermentation & - & - \\
Growth at $25^{\circ} \mathrm{C}$ & + & + \\
$30^{\circ} \mathrm{C}$ & + & + \\
$37^{\circ} \mathrm{C}$ & + & + \\
$42^{\circ} \mathrm{C}$ & + & - \\
Growth at pH 5 & - & + \\
pH 6 & + & + \\
pH 7 & + & + \\
pH 8 & + & + \\
\hline & & + \\
\hline
\end{tabular}


The two bacteria strain BP4 and strain BP6 was isolated from waste soil, so both may have adapted to waste soil where a lot of plastic waste is disposed. Several studies have been conducted to detect plastic-degrading bacteria using bacteria isolated from waste disposal soil. The ability of Bacillus bacteria to degrade plastic in this study was higher than that of $B$. cereus which was also isolated from waste soil with a degradation percentage of $6.33 \%$ for 60 days of incubation (Lalina et al. 2021). The results of this study are also higher than the bacteria Bacillus ISJ51 Gupta and Devi (2019) with a plastic degradation percentage of $1.5 \%$ within 60 days of incubation. The results of this study were lower than $B$. siamens Lalina et al. (2021) with a degradation percentage of $8.46 \%$ for 60 days of incubation. However, in the present study, the incubation only 30 days, while in other studies the incubation time for Bacillus was longer such as 60 and 90 days (Gupta and Devi 2019; Lalina et al. 2021). The incubation time also affects the percentage of LDPE plastic degradation. Sen and Raut (2015) state that LDPE biodegradation is influenced by several factors, namely LDPE characteristics, types of microorganisms, and pretreatment. Pre-treatment such as chopping and UV irradiation can also accelerate the degradation of LDPE plastic. Pre-treatment will cause the plastic to be fragmented into smaller sizes, thus accelerating the biodegradation process. Result indicate that these two bacterial strain have the potential to be used as biodegradation agents for LDPE plastic. In testing the biodegradation of plastics in addition to reducing the weight of plastic, other tests are needed such as analysis of changes in the plastic surface, and analysis of changes in biochemical compounds.

\section{Morphological and biochemical characterization}

The results of the biochemical and morphological character tests of the two isolates of strain BP4 and strain BP6 are Gram-positive rod-shaped bacteria. This is as reported by Bisen et al. (2012) which states that the genus Bacillus is in the form of bacilli and is gram-positive. The cell wall of gram-positive bacteria is thicker than that of gram-negative bacteria. When given $96 \%$ alcohol bleach, dehydration will occur so that the pores of the cell walls close and prevent the dissolution of the crystal violet-iodine complex, and remain stained with crystal violet-purple paint until the end of the gram stain. Gram-negative bacteria have a thick lipid layer that dissolves when alcohol is added. Cell wall pores will be larger and will be stained pink with safranin. Test Carbohydrates will be fermented into alcohol, acid, and gas depending on the type of carbohydrate and also the ability of the test bacteria. The formation of acid is indicated by a change in the color of the indicator in the medium, which will cause a change in the color of the medium from red to yellow. The enzyme that plays a role in glucose fermentation is the glucosidase enzyme. The enzyme that plays a role in the fermentation of sucrose is the enzyme sucrase which will break down sucrose into glucose and fructose. The enzyme that plays a role in lactose fermentation is the lactase enzyme which breaks down lactose into glucose and galactose Bisen et al. (2012). Both strain Bp4 and strain BP6 can produce glucosidase enzymes. The ability to ferment glucose was indicated by a change in the color of the test medium from red to yellow.

The catalase test result of both Bacillus sp. strain BP4 and BP6 showed positive test. According to Bisen et al. (2012), catalase test was used to detect the presence or absence of the catalase enzyme. A positive catalase test indicates that the bacteria are capable of producing the enzyme catalase. The enzyme catalase serves to neutralize the bactericidal effect of hydrogen peroxide. The catalase enzyme will break down $\mathrm{H}_{2} \mathrm{O}_{2}$ into $\mathrm{H}_{2} \mathrm{O}$ and $\mathrm{O}_{2}$. This reaction was marked by the formation of oxygen bubbles, on the bacterial isolates dripped with $\mathrm{H}_{2} \mathrm{O}_{2}$. The motility result test of both Bacillus sp. showed positive test. Motility or movement of bacteria can be either passive movement or active movement. In active movement, bacteria move with the help of locomotion called flagella. In passive movement, bacteria move caused by Brownian motion originating from external factors Bisen et al. (2012). Both Bacillus sp. isolates were able to growth in a temperature range $25-42^{\circ} \mathrm{C}$ and a $\mathrm{pH}$ range 6-8. According to Bisen et al. (2012) Bacillus strain BP4 and BP6 belong to group of mesophilic bacteria which can grow in the range temperature $25-40^{\circ} \mathrm{C}$. Both strain Bacillus belong to group of neutrofilik which can grow in range $\mathrm{pH}$ 5-8.

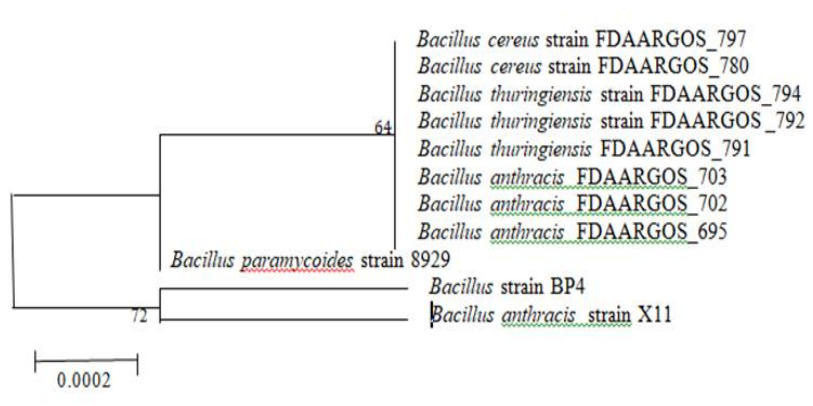

Figure 3. Phylogenetic tree of Bacillus strain BP4

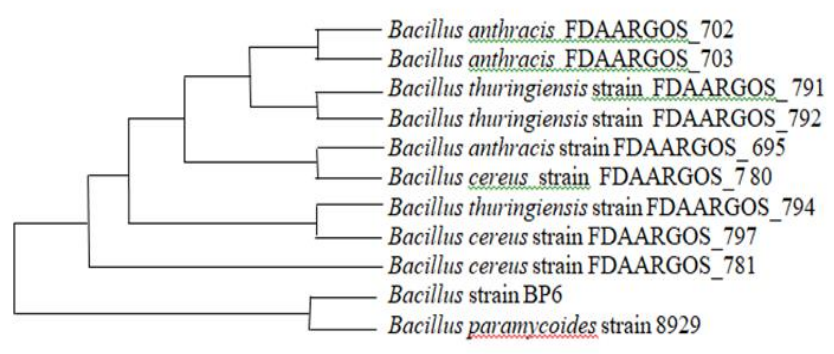

Figure 4. Phylogenetic tree of Bacillus strain BP6 
The results of morphological characterization and biochemical tests of Bacillus sp. strain BP4 were stem cell shape, medium cell size, gram-positive, circular colony shape, entire colony edge, raised colony elevation, white colony color, catalase-positive, motile, able to ferment glucose, able to grow at $25-42^{\circ} \mathrm{C}$ and able to grow in the $\mathrm{pH}$ range of 6-8. The results of morphological and biochemical characterization of Bacillus sp. strain BP6 stem cell shape, medium size, irregular colony shape, entire colony edge, raised colony elevation, cloudy white colony color, catalase-positive, motile, able to ferment glucose, able to grow at a temperature of $25-37^{\circ} \mathrm{C}$, and able to grow in a $\mathrm{pH}$ range of 5-8.

\section{Molecular identification}

According to Tindall (2010) bacteria can be grouped into one species if they have more than $97 \%$ similarity in the $16 \mathrm{~S}$ rRNA gene sequence. Results of molecular identification revealed that Bacillus sp. strain BP4 showed similarity of $16 \mathrm{~S}$ rRNA gene sequences of $99.72 \%$ with $B$. paramycoides strain 8929. However, it also showed similarity of $99.72 \%$ with $B$. anthracis strain X11. Based on the $16 \mathrm{~S}$ rRNA gene sequence, there are 273 species of Bacillus grouped into 10 groups, namely: group B. subtilis, $B$. pumilus, Bacillus licheniformis, $B$. simplex, $B$. megaterium, B. cereus, B. smithii, B. firmus, B. coagulans, and $B$. alcalophilus. The $B$. cereus group consists of, $B$. cereus, $B$. pseudomycoides, B. mycoides, B. thuringiensis, $B$. anthracis and $B$. weihenstephanensis. The results of the $16 \mathrm{~S}$ rRNA gene sequence showed that the two local Riau bacterial strains, namely strain BP4 and strain BP6 were included in the B.cereus group. In the B. cereus group, the similarity of $16 \mathrm{~S}$ rRNA gene sequences between different species exceeded the species lineage limit by $97 \%$ (Amaresan et al. 2020). This was especially true for group $B$. subtilis and group B. cereus. The polyphasic approach often fails to identify Bacillus species in the B. cereus group because the species belonging to this group have very close similarities. This also happened to Bacillus sp. strain BP4 where the results of the BLASTn analysis showed a similarity of $99.72 \%$ with $B$. paramycoides strain 8229 and also showed a similarity of $99.72 \%$ with $B$. anthracis strain X11. The recommended alternative method for identifying group B. cereus and group B. subtilis is single sequencing markers or core genes such as gyrB, cheA, rpoB. Another method is the total DNA sequence DNA hybridization, a classification based on the whole genome sequence (Amaresan et al. 2020). Mandel et al. (2020) also stated that the bacteria B. cereus, B. antrachis, $B$. paramycoides, and $B$. mycoides cluster with $B$. cereus based on their similarity. This is also shown in the two phylogenetic trees (Figure 3 and Figure 4) where B. cereus, $B$. thuringiensis, $B$. anthracis, and $B$. paramycoides are in one cluster. Based on several characters possessed by $B$. anthracis, it is stated that $B$. anthracis is the development of a new species originating from $B$. cereus. Bacteria of the genus Bacillus are commonly found in soil and some can grow in lakes and seas. Only a few of the genus Bacillus cause disease in humans.
The genus Bacillus consists of 268 species and 7 subspecies, two species are known to cause disease in humans, namely $B$. anthracis which causes anthrax disease, and $B$. cereus which causes disease with symptoms similar to food poisoning (Amaresan et al. 2020). The result revealed that Bacillus sp. strain $\mathrm{BP} 4$ is suspected to be a species of B. anthracis. However, because Bacillus sp. strain BP4 was suspected to be $B$. paramycoides or $B$. anthracis. Further testing is needed to determine this bacterial species. If Bacillus sp. strain BP4 is B. anthracis, it cannot be used as a bioremediation agent because it is a pathogenic bacterium in humans. Although it can degrade LDPE for sure, this bacterium cannot be used as bioremediation agents because it is pathogenic. According to WHO (2008) and Dutta et al. (2011), B. anthracis is a pathogenic bacterium that causes anthrax disease.

The results of the molecular identification of Bacillus sp. strain BP6 bacteria produced DNA bands 1439 bp. Furthermore, BLASTn analysis was carried out to see the similarity with other bacterial sequences in the gene bank. The results of the phylogenetic analysis showed that Bacillus strain BP6 had sequence similarity of $99.3 \%$ with B. paramycoides strain 8929 . The research results by Liu et al. (2017) reported that B. paramycoides is a Bacillusshaped, Gram-positive, non-motile bacterium. Colonies are medium in size and white in color. Bacillus paramycoides is one of 9 new species belonging to the B. cereus group. Based on a polyphasic taxonomic approach to the analysis of $16 \mathrm{~S}$ rRNA gene sequences, this strain belongs to the group B. cereus, shares more than $97 \%$ similarities with species from this group, and less than $95 \%$ similarities with other species of the genus Bacillus. The results of the phylogenetic tree analysis are shown $B$. paramycoides phylogenetically is a group of $B$. cereus, it is suspected that this group is widely distributed and has different ecological and evolutionary roles in the terrestrial environment (Liu et al. 2017). Several studies have also succeeded in isolating $B$. paramycoides from various sources with various abilities such as thermophilic $B$. paramycoides isolated from volcanic craters (Safitri et al. 2020), some $B$. paramycoides act as bioremediation agents such as hospital waste remediation (Rashid et al. 2020), acephate biodegradation (Ren et al. 2020), chlorpyrifos degradation (Rochaddi et al. 2019).

This research is the first to be conducted on the exploration of LDPE plastic-degrading bacteria in Pekanbaru, Riau, Indonesia. The results exhibited that both the bacteria played an important role in overcoming accumulation of plastic waste in the soil. The result of molecular identification showed that Bacillus sp. strain BP4 was suspected to be B. paramycoides strain 8229 or $B$. anthracis strain X11. Bacillus sp. strain BP6 showed similarity with $B$. paramycoides strain 8929 . Both bacteria showed the ability to degrade LDPE plastic. $B$. paramycoides strain BP6 has the potential to be used as a plastic decomposition agent. This research is a preliminary study and further research is needed on the surface analysis of the plastic and the compounds produced and optimization of environmental factors. 


\section{ACKNOWLEDGEMENTS}

The authors would like to thank the LPPM University of Riau and the Ministry of Research, Technology and Higher Education (Ristekdikti), for funding this research under the research DRPM Grant. Contract Number: 488/UN.19.5.1.3/PT.0103/2021.

\section{REFERENCES}

Amaresan N, Kumar MS, Annapurna K, Kumar K, Sankaranarayanan A, editors. 2020. Beneficial Microbes in Agro-Ecology: Bacteria and Fungi. Academic Press, London, UK.

Alshehrei F. 2017. Biodegradation of synthetic and natural plastic by microorganisms. J Appl Environ Microbiol 5 (1): 8-19.

Basori RA. 2016. Analysis of waste utilization potential of plastic bags in the Pekanbaru City. [Thesis]. Riau University, Pekanbaru. [Indonesian]

Bennett JE, Dolin R, Blaser MJ. 2014. Mandell, douglas, and bennett's principles and practice of infectious diseases: 2-volume set (Vol. 2). Elsevier Health Sciences, Philadelphia.

Bisen P, Prasad GKBS, Debnath M. 2012. Microbe concepts and application. Willey Blackwell, New York. DOI: 10.1002/9781118311912.

de Souza Machado AA, Lau CW, Till J, Kloas W, Lehmann A, Becker R, Rillig MC. 2018. Impacts of microplastics on the soil biophysical environment. Environ Sci Technol 52 (17): 9656-9665. DOI 10.1021/acs.est.8b02212.

Dutta TK, Sujatha S, Sahoo RK. 2011. Anthrax update on diagnosis and management. J Assoc Phys India 59 (9): 573.

Gu JD. 2003. Microbiological deterioration and degradation of synthetic polymeric materials: recent research advances. Intl Biodeterior Biodegrad 52: 69-91. DOI: 10.1016/S0964-8305(02)00177-4.

Gupta KK, Devi D. 2019. Biodegradation of low-density polyethylene by selected Bacillus sp. J Sci 32 (3): 802-813. DOI: 10.35378/gujs.496392.

He P, Chen L, Shao L, Zhang H, Lü F. 2019. Municipal solid waste (MSW) landfill: A source of microplastics?-Evidence of microplastics in landfill leachate. Water Res 159: 38-45. DOI: 10.1016/j.watres.2019.04.060.

Kyaw BM, Champakalakshmi R, Sakharkar MK, Lim CS, Sakharkar KR. 2012. Biodegradation of low-density polythene (LDPE) by Pseudomonas species. Indian J Microbiol 52 (3): 411-419. DOI 10.1007/s12088-012-0250-6.

Lalina M, Ibrar KI, Yoo HS, Kim S, Park HT, Ahmad B, Azam S. 2021 Identification and characterization of low-density polyethylenedegrading bacteria isolated from soils of waste disposal sites. Environ Eng Res 26 (3): 200167.
Liu Y, Du J, Lai Q, Zeng R, Dezan Ye D, Xu J, Shao Z. 2017. Proposal of nine novel species of the Bacillus cereus group. J Syst Evol Microbiol 67 (8): 2499-2508. DOI: 10.1099/ijsem.0.001821.

Nielsen TD, Holmberg K, Stripple J. 2019. Need a bag? A review of public policies on plastic carrier bags-Where, how and to what effect? Waste Manag 87: 428-440. DOI: 10.1016/j.wasman.2019.02.025.

Rashid A, Mirza SA, Keating C, Ali S, Campos LC. 2020. Indigenous Bacillus paramycoides spp. and Alcaligenes faecalis: sustainable solution for bioremediation of hospital wastewater. Environ Technol 1-14. DOI: 10.1080/09593330.2020.1858180.

Raziyafathima M, Praseetha PK, Rimal IRS. 2016. Microbial degradation of plastic waste: A review. J Pharm Chem Biol Sci 4 (2): 231-242.

Ren J, Wang C, Li C, Fan B, Niu D. 2020. Biodegradation of acephate by Bacillus paramycoides NDZ and its degradation pathway. World J Microbiol Biotechnol 36 (10): 1-11. DOI: 10.1007/s11274-02002931-1.

Rochaddi B, Zainuri M, Sabdono A. 2019. Diversity of Chlorpyrifosdegrading bacteria isolated from shallow aquifer of East Java Coastal Settlements, Indonesia. Biodiversitas J Biol Divers 20 (12). DOI: 10.13057/biodiv/d201227.

Safitri R, Kusumawardani DP, Annisa, Partasasmita ruhyat, Asharina S, Maskoen AM. 2020. Characterization and identification of three thermophilic Bacillus strain isolated from Domas Crater, Mt. Tangkuban Perahu, Indonesia. Biodiversitas 21 (8): 3444-3453. DOI: 10.13057/biodiv/d210805.

Sen SK, Raut S. 2015. Microbial degradation of low density polyethylene (LDPE): A review. J Environ Chem Eng 3 (1): 462-473. DOI: 10.1016/j.jece.2015.01.003

Sharma A, Sharma A. 2004. Degradation assessment of low-density polythene (LDP) and Polythene (PP) by an indigenous isolate of Pseudomonas stutzeri. J Sci Ind Res 63: 293-296.

Suresh B, Maruthamuthu S, Palanisamy N, Ragunathan R, Pandiyaraj KN. 2011. Investigation on biodegradability of polyethylene by Bacillus cereus strain masu isolated from compost soil. Res J Microbiol 2: 292-302.

Tamura K, Stecher G, Peterson D, Nel M. 2011. MEGA5: molecular evolutionary genetics analysis using maximum-likelihood, evolutionary distance, and maximum parsimony methods. Mol Biol Evol 28 (10): 2731-2739. DOI: 10.1093/molbev/msr121.

Tindall BJ, Rosselló-Móra R, Busse HJ, Ludwig W, Kämpfer P. 2010. Notes on the characterization of prokaryote strains for taxonomic purposes. Intl J Syst Evol Microbiol 60: 249-266. DOI: 10.1099/ijs.0.016949-0.

Tosetto L, Brown C, Williamson JE.2016, Microplastics on beaches: Ingestion and behavioural consequences for beachhoppers. Mar Biol 163 (10): 1-13. DOI: 10.1007/s00227-016-2973-0.

Watanabe T, Ohtake Y, Asabe H, Murakami N, Furukawa M. 2009. Biodegradability and degrading microbes of low-density polyethylene. J Appl Polym Sci 111 (1): 551-559. DOI: 10.1002/app.29102.

World Health Organization (WHO). 2008 Anthrax in humans and animals. 4th ed. Geneva: The Organization 4 (1): 36-42. 